\title{
Demographic and Clinical Characteristics of Patients with Epilepsy Admitting to Neurology Outpatient Clinic of Erzincan University Mengucek Gazi Training and Research Hospital
}

\author{
Erzincan Üniversitesi Mengücek Gazi Eğitim ve Araştırma Hastanesi Nöroloji
} Polikliniği’ne Başvuran Epilepsi Hastalarının Demografik ve Klinik Özellikleri

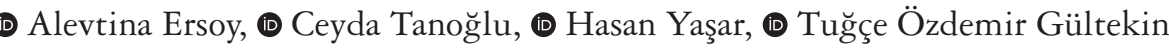 \\ Erzincan University Mengucek Gazi Training and Research Hospital, Clinic of Neurology, Erzincan, Turkey
}

\begin{abstract}
Objective: The aim of this study was to evaluatethe demographic and clinical findings of patients with epilepsy in Erzincan.

Materials and Methods: Five hundred forty-eight adult patients with epilepsy who were admitted to the neurology outpatient clinic between January 2016 and August 2017 were included in the study. Patients' age, sex, duration of epilepsy, risk factors, seizure frequency and type, number of drugs used, comorbid diseases, electroencephalography (EEG), and neuroimaging results were evaluated retrospectively.

Results: Two hundred eighty-three patients were men (51.6\%), 265 were women (48.4\%). The mean age was $40.64 \pm 17.9$ years, and the mean illness duration was $11 \pm 11$ years. Risk factors of epilepsy were found in $52.2 \%$ of the patients. Pathologic findings in neuroimaging were found in $46.8 \%$ of patients, and $48.2 \%$ of patients had pathologic findings in EEG. Thirteen percent of patients had more than one seizure per month, $8.9 \%$ of patients had a seizure-free period for five years. Focal-onset seizures were present in $54.8 \%$ of patients and generalized- onset seizures were present in $44.5 \%$ of patients. monotherapy was received by $58.9 \%$ of the patients, and $40.3 \%$ of the patients received polytherapy. Epilepsy was accompanied by other diseases in $27.7 \%$ of the patients. There was no significant difference between the sexes in terms of age of onset and duration, seizure frequency, number of medications used, psychiatric comorbidity, the presence of pathologic findings in EEG, and neuroimaging ( $>0.05$ ). Patients with pathological findings in neuroimaging were significantly older than 18 years of age $(\mathrm{p}=0.004)$. Pathologic EEG findings were detected more frequently in the same patients $(\mathrm{p}=0.001)$. Patients with psychiatric symptoms had longer epilepsy duration ( $\mathrm{p}=0.005)$, and the number of antiepileptic drugs used was higher $(\mathrm{p}<0.001)$.

Conclusion: Epilepsy does not show sex differences in terms of many features. In patients with adult-onset epilepsy, pathologic findings are common in neuroimaging and EEG. Comorbid psychiatric disorders are associated with a longer and more resistant course of epilepsy.
\end{abstract}

Keywords: Epilepsy, epidemiology, neuroimaging, comorbidity

$\ddot{O} \mathbf{z}$

Amaç: Bu çalışmanın amacı; Erzincan ilinde epilepsi hastalarının demografik ve klinik özelliklerini incelemektir.

Gereç ve Yöntem: Erzincan Üniversitesi Mengücek Gazi Eğitim ve Araştırma Hastanesi Nöroloji Polikliniği’ne Ocak 2016-Ağustos 2017 tarihleri arasında başvuran yetişkin 548 epilepsi hastası dahil edildi. Hastaların yaş, cinsiyet, epilepsi süresi, risk faktörleri, nöbet sıklığı ve tipi, kullanılan ilaç sayısı, komorbid hastalıklar, elektroensefalografi (EEG) ve nörogörüntüleme sonuçları retrospektif olarak değerlendirildi.

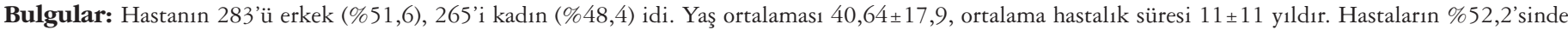
epilepsi risk faktörleri saptandı. Hastaların \%46,8'inde nörogörüntülemede, \%48,2'sinde ise EEG'de patolojik bulgu saptandı. Hastaların \%13’ü ayda birden fazla nöbet geçiriyordu. Hastaların \% 8,9'unda beş yıldır nöbetsizlik dönemi mevcuttu. Hastaların \%54,8'inde fokal, \%44,5'inde jeneralize başlangıçlı nöbet türü mevcuttu. Hastaların \%58,9’u monoterapi, \%40,3’ü politerapi almaktaydı. Hastaların \%27,7’sinde epilepsiye diğer hastalıklar eşlik etmekteydi. Cinsiyetler

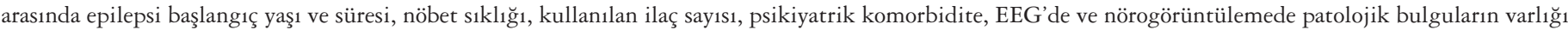
açısından anlamlı fark bulunmamıştı ( $\mathrm{p}>0,05)$. On sekiz yaş ve üzeri epilepsi hastalarında nörogörüntülemede patolojik bulgu anlamlı olarak yüksekti ( $\mathrm{p}=0,004)$. Aynı hastalarda EEG bozukluğu daha sık saptanmıştı ( $\mathrm{p}=0,001$ ). Epilepsi süresi, psikiyatrik semptomları olanlarda olmayanlara göre daha uzun ( $\mathrm{p}=0,005)$, kullanılan antiepileptik ilaç sayısı daha fazlaydı $(\mathrm{p}=0,000)$.

Sonuç: Epilepsi birçok özelliği açısından cinsiyet farkı göstermemektedir. Erişkin başlangıçlı epilepsi hastalarında nörogörüntüleme ve EEG'de patolojik bulgulara sık rastlanmaktadır. Psikiyatrik hastalıkların eşlik etmesi epilepsinin daha uzun ve dirençli seyri ile ilişkilidir.

Anahtar Kelimeler: Epilepsi, epidemiyoloji, nörogörüntüleme, komorbidite

Address for Correspondence/Yazışma Adresi: Alevtina Ersoy MD, Erzincan University Mengucek Gazi Training and Research Hospital, Clinic of Neurology, Erzincan, Turkey

Phone: +90 5332145569 E-mail: alevtina_ersoy@hotmail.com ORCID ID: orcid.org/0000-0002-4968-0786

Received/Geliş Tarihi: 12.12 .2017 Accepted/Kabul Tarihi: 25.03 .2018

Published in: This study was presented as an e-poster in the $53^{\text {rd }}$. National Neurology Congress (TEP-58).

${ }^{\circledR}$ Copyright 2018 by Turkish Neurological Society

Turkish Journal of Neurology published by Galenos Publishing House 


\section{Introduction}

Epilepsy is a chronic cerebral disorder characterized by permanent susceptibility to epileptic seizures, which causes neuro biologic, cognitive, psychological, and social problems. An epileptic seizure is a transient condition characterized by findings and/or symptoms caused by abnormal excessive or synchronous neuronal activity (1).

The prevalence of epilepsy varies from country to country. The prevalence of epilepsy in European countries in patients aged between 20 and 64 years of is 6/1000 and 8/1000 in those aged over 65 years. The average prevalence of epilepsy in industrialized countries is 6/1000 (2). In developing countries, the highest prevalence rates are reported in Liberia (49/1000), and Panama Guaymi natives (59/1000), and the average prevalence of epilepsy is $18.5 / 1000$ (3). The variability of prevalence among developed and developing countries is thought to be due to the low socioeconomic status of developing countries; poor health education of people; geographic, environmental, ethnic, and cultural factors; genetic predisposition; country-specific infections; as well as methodologic differences $(4,5)$.

Epidemiologic studies have been conducted in different regions of our country, but limited populations have been examined in most of them. According to the studies performed after 2010, the prevalence epilepsy in Turkey varies between 5.7-8.94/1000 $(6,7,8,9)$.

Epilepsy is a chronic treatable disease that is seen all over the world regardless of sex and age, without any age limit. Epilepsy affects approximately 100 million people, and $80 \%$ of them live in developing countries. Knowing epilepsy well, correct diagnosis, appropriate treatment, and improving the quality of life of patients with epilepsy means bringing these patients to the community. Unfortunately, more than half of people who need antiepileptic treatment do not receive this treatment (10).

Inadequate treatment ranges from $10 \%$ in countries with high income, $50 \%$ in countries with moderate income, and $75 \%$ in countries with low income. Inadequate treatment rates in countries also vary. The rate of treatment in rural areas is generally lower than in urban areas. It is believed that inadequate treatment is due to the inability to recognize the disease by physicians, the cost of treatment, inability to find drugs, and cultural beliefs (11).

The importance of epidemiologic and descriptive studies in the adoption of the disease to society, raising awareness about the disease, reducing inadequate treatment, recognizing the social, economic, and physical effects caused by epilepsy cannot be underestimated. Much information about the natural course of the disease, risk factors, etiology, comorbidity, and mortality is obtained from these studies. On the other hand, information obtained from these studies is needed to develop new strategies and approaches in treatment and follow-up and to determine techniques to prevent the development of the disease (12).

It has been shown that the establishment of epilepsy polyclinics in hospitals increases the regular follow-up of patients with epilepsy, the success of treatment, and improves the rate of seizures, the adoption of patients to treatment, and quality of life $(13,14)$. In this study, we aimed to evaluate the status of epilepsy in Erzincan.

\section{Materials and Methods}

Five hundred forty-eight adult patients with epilepsy who were admitted to the neurology polyclinic of Erzincan University Mengucek Gazi Training and Research Hospital between January 2016 and August 2017 were included in this retrospective study. Patients using prophylactic antiepileptic drugs after surgery, patients who were followed up elsewhere and who came to get their drugs prescribed, and those having only psychogenic seizures were excluded. Data including age, sex, duration of epilepsy, risk factors, frequency and type of seizures, number of drugs used, comorbid diseases not related with epilepsy, electroencephalography (EEG) and neuroimaging [computerized cranial tomography (CCT) or cranial magnetic resonance imaging (MRI)] results were obtained from the database used in our hospital.

\section{Statistical Analysis}

Statistical analysis was performed using the SPSS 17.0 package program. Frequency analysis was used for basic descriptive statistics. In order to compare patients with epilepsy according to sex, the existence of psychiatric disease, and pathologic findings in neuroimaging, patients without these characteristics were randomly selected and grouped equally with patients with these characteristics. The chi-square compatibility test was used to evaluate the equality of groups. The chi-square independence test was used to compare the groups. Statistical significance was accepted as $\mathrm{p}<0.05$.

\section{Results}

Of 548 patients, $283(51.6 \%)$ were males, and 265 (48.4\%) were females, and the difference between the groups was not significant $(\mathrm{p}=0.44)$. Table 1 shows the characteristics of the

Table 1. Distribution of the patients by sex and features of the diseases of the patients

\begin{tabular}{|llll|} 
Variables & & Number & $\%$ \\
\multirow{3}{*}{ Age of onset } & Male & 283 & 51.6 \\
& Female & 265 & 48.4 \\
\multirow{2}{*}{ Risk factors } & $<18$ years & 192 & 35.0 \\
& 18-50 years & 252 & 46.0 \\
& $>50$ years & 104 & 19.0 \\
Pathologic finding in EEG & Yes & 286 & 52.2 \\
& No & 262 & 47.8 \\
Pathologic finding in & Yes & 259 & 48.2 \\
neuroimaging & No & 278 & 51.8 \\
\multirow{2}{*}{ Seizure status } & Continuing & 301 & 46.8 \\
& seizures & 54.9 \\
Treatment & No seziures & 247 & 45.1 \\
EEG: Electroencephalography & Monotherapy & 323 & 59.4 \\
\hline
\end{tabular}


patients' diseases and sex distribution of the patients in the study group. The mean age was $40.64 \pm 17.9$ (range, 18-93) years. The longest duration of illness was 57 years, and the average duration of illness was $11 \pm 11$ years. One hundred ninety-two patients $(35.0 \%)$ had the disease before the age of 18 years. Twenty-four of these patients $(12.5 \%)$ had been diagnosed as having epilepsy at the age of 0 . Two hundred fifty-two patients (46\%) had epilepsy between the ages of 18 and 50 years, 104 patients (19\%) had epilepsy after the age of 50 years.

Two hundred eighty-six patients (52.2\%) had epilepsy risk factors. Of all the patients included in the study, 193 patients $(35.2 \%)$ had epilepsy or febrile seizures in childhood, $100(18.3 \%)$ had perinatal pathology, $45(8.2 \%)$ had intracranial operation, 13 $(2.4 \%)$ had head trauma, $54(9.9 \%)$ had cerebrovascular pathology, $31(5.7 \%)$ had brain tumors, $13(2.4 \%)$ had dementia, $18(3.3 \%)$ had a family history of epilepsy, $4(0.8 \%)$ had encephalopathy, 8 $(1.5 \%)$ had central nervous system (CNS) infections, $6(1.2 \%)$ had congenital diseases, and $17(3.1 \%)$ had other disorders that formed a risk factor (Table 2 ).

Five hundred thirty-nine patients underwent neuroimaging (CCT or MRI), and 535 patients underwent interictal EEG examination during the last admission. Pathologic findings were found in neuroimaging of 252 patients $(46.8 \%)$ and in EEG of 259 patients $(48.2 \%)$. One hundred ninety-seven patients $(78.2 \%)$ had one, $50(19.8 \%)$ had two, $5(2.0 \%)$ had three different radiologic pathologies. In one hundred thirty patients $(51.6 \%)$ there were non-specific white matter lesions, $91(36.1 \%)$ had encephalomalacia, $42(16.7 \%)$ had cerebral atrophy, $13(5.2 \%)$ had intracranial mass, $16(6.3 \%)$ had temporal lobe lesions, $3(1.2 \%)$ had vascular pathology, $9(3.6 \%)$ had hydrocephalus, $5(2 \%)$ had congenital pathology, 3 patient $(1.2 \%)$ had calcification, $1(0.4 \%)$ had demyelinating plaques, and a corpus callosum lesion was found in 1 patient $(0.4 \%)$ (Table 3 ).

Thirteen patients $(2.4 \%)$ had more than 10 seizures per month, $58(10.6 \%)$ had $1-10$ seizures per month, and $230(42.0 \%)$ had 1-11 seizures per year. Sixty-nine patients $(12.6 \%)$ were seizurefree for one year, 42 patients $(7.7 \%)$ for three years, and 49 patients $(8.9 \%)$ for five years. Eighty-seven patients $(15.9 \%)$ were seizurefree since the beginning of treatment (Table 4).

Focal-onset seizure type was detected in 300 patients $(54.8 \%)$, $244(44.5 \%)$ had generalized-onset seizure type, $4(0.7 \%)$ had epileptic seizures with pseudo seizures, $8(1.5 \%)$ had hot water epilepsy, and 2 patients $(0.4 \%)$ had menstrual epilepsy. The distribution of seizure types is shown in Table 5.

Three hundred twenty-three patients $(58.9 \%)$ were receiving one drug, $153(27.9 \%)$ received two, $48(8.8 \%)$ had three, 16 $(2.9 \%)$ had four, and 4 patients $(0.7 \%)$ received five antiepileptic drugs. The treatment of four patients $(0.7 \%)$ had been terminated.

One hundred fifty-two patients $(27.7 \%)$ had other diseases not related to the etiology of epilepsy. There were 83 patients (15.2\%) with psychiatric disorders, $37(6.7 \%)$ had cardiovascular disorders, $10(1.8 \%)$ had disorders of thyroid gland, $6(1.1 \%)$ had respiratory system disorders, $4(0.8 \%)$ had autoimmune diseases, $5(0.9 \%)$ had oncologic diseases not involving brain, $3(0.6 \%)$ had renal diseases, and 4 patients $(0.8 \%)$ had other diseases as comorbidities (Table 6).

There was no significant difference between the ages of onset of epilepsy, the duration of epilepsy, the number of drugs used,

\section{Table 2. Risk factors*}

\begin{tabular}{|c|c|c|}
\hline Risk factors & Number & $\%$ \\
\hline $\begin{array}{l}\text { Epilepsy and/or febrile seizure history in } \\
\text { childhood }\end{array}$ & 193 & 35.2 \\
\hline Epilepsy history in family & 18 & 3.3 \\
\hline \multicolumn{3}{|l|}{ Perinatal pathology associated } \\
\hline - Mental retardation & 63 & 11.5 \\
\hline - Cerebral palsy & 37 & 6.8 \\
\hline Intracranial operation & 45 & 8.2 \\
\hline Head trauma & 13 & 2.4 \\
\hline Cerebrovascular pathology & 54 & 9.9 \\
\hline - Aneurysm & 7 & 1.3 \\
\hline - Arterio-venous malformation & 2 & 0.4 \\
\hline - Venous cavernoma & 1 & 0.2 \\
\hline - Venous sinus thrombosis & 1 & 0.2 \\
\hline - Intracranial hemorrhage & 23 & 4.2 \\
\hline - Ischemic stroke & 20 & 3.7 \\
\hline Brain tumor & 31 & 5.7 \\
\hline Dementia & 13 & 2.4 \\
\hline Encephalopathy & 4 & 0.8 \\
\hline - Hypertensive & 1 & 0.2 \\
\hline - Hypoxic & 1 & 0.2 \\
\hline - PRES & 1 & 0.2 \\
\hline - Posttraumatic & 1 & 0.2 \\
\hline Central nervous system infection & 8 & 1.5 \\
\hline - Herpes virus encephalitis & 2 & 0.4 \\
\hline - Neurobrucellosis & 1 & 0.2 \\
\hline - Meningitis sequela & 4 & 0.8 \\
\hline - SSPE & 1 & 0.2 \\
\hline $\begin{array}{l}\text { Congenital/genetic metabolic and } \\
\text { degenerative diseases }\end{array}$ & 6 & 1.2 \\
\hline - Phenylketonuria & 2 & 0.4 \\
\hline - Tuberous sclerosis & 1 & 0.2 \\
\hline - Sturge-Weber disease & 1 & 0.2 \\
\hline - Van der Knaap disease & 1 & 0.2 \\
\hline - Fahr disease & 1 & 0.2 \\
\hline Others & 17 & 3.1 \\
\hline - Benign intracranial hypotension & 1 & 0.2 \\
\hline - Neurosarcoidosis & 1 & 0.2 \\
\hline - Hydrocephalus & 4 & 0.8 \\
\hline - Migraine & 9 & 1.8 \\
\hline - Dysmenorrhea & 2 & 0.4 \\
\hline
\end{tabular}


psychiatric comorbidity, and the presence of pathologic findings in EEG and neuroimaging ( $\mathrm{p}>0.05$ ) (Table 7).

In patients with changes in neuroimaging studies, the onset of epilepsy was detected at the age of 18 years and older $(p=0.007)$. In the same patients, pathologic findings in EEG were more frequent $(p=0.001)$. The number of antiepileptic drugs used, duration of epilepsy, and whether seizures continued did not change between patients with and without abnormal neuroimaging findings ( $\mathrm{p}>0.05)$ (Table 8$)$.

The duration of epilepsy was longer $(\mathrm{p}=0.005)$, and the number of antiepileptic drugs used was higher $(\mathrm{p}<0.001)$ in patients with psychiatric symptoms compared with those without psychiatric

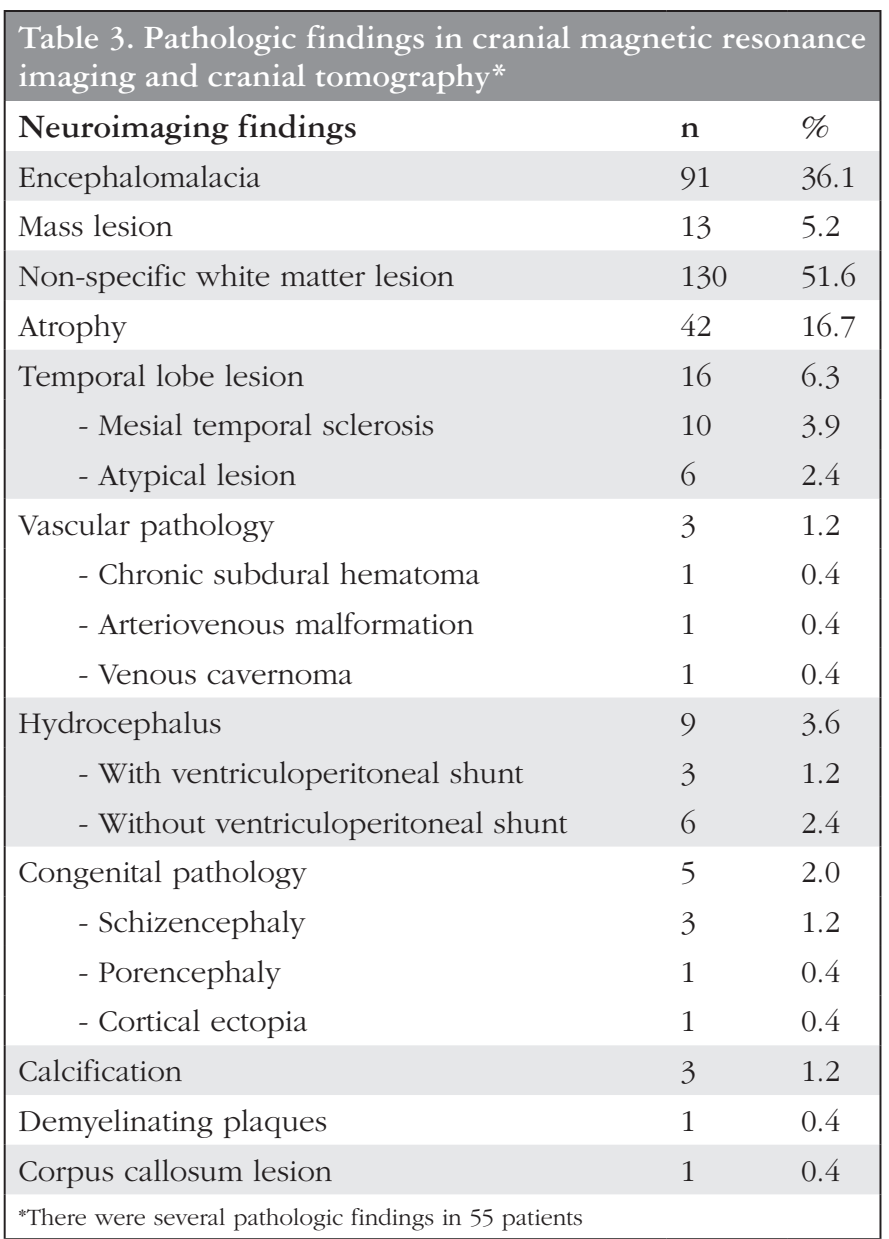

\begin{tabular}{|lll|}
\hline Table 4. Seizure frequency & & \\
\hline Seizure frequency & $\mathrm{n}$ & $\%$ \\
$>10$ per month & 13 & 2.4 \\
1-10 per month & 58 & 10.6 \\
1-11 per year & 230 & 42.0 \\
No seizures for one year & 69 & 12.6 \\
No seizures for three years & 42 & 7.7 \\
No seizures for five years & 49 & 8.9 \\
No seizures since treatment initiation & 87 & 15.9 \\
\hline
\end{tabular}

symptoms. There were no differences in terms of the presence of abnormalities in EEG, whether seizures continued, and the age of onset of epilepsy between patients with and without psychiatric disease $(\mathrm{p}>0.05)$ (Table 9).

\begin{tabular}{|llll|}
\hline Table 5. Seizure types & & & \\
Seizure types & $\mathbf{n}$ & $\begin{array}{l}\% \text { per } \\
\text { group }\end{array}$ & $\begin{array}{l}\% \\
\text { total }\end{array}$ \\
Partial-onset & 300 & & \\
$\quad$ - Simple partial & 58 & 19.3 & 54.8 \\
$\quad$ - Complex partial & 66 & 22.0 & \\
$\quad$ - Secondary generalized & 176 & 58.7 & \\
Generalized-onset & 244 & & \\
$\quad$ - Motor & 237 & 97.1 & 44.5 \\
$\quad$ - Non-motor & 7 & 2.9 & \\
Pseudoseizure+seizure & 4 & & 0.7 \\
\hline
\end{tabular}

\section{Table 6. Comorbid diseases associated with epilepsy}

\begin{tabular}{|c|c|c|}
\hline Comorbid diseases & $\mathrm{n}$ & $\%$ \\
\hline Psychiatric diseases & 83 & 15.2 \\
\hline - Depression & 24 & 4.4 \\
\hline - Anxiety disorder & 21 & 3.8 \\
\hline - Bipolar disorder & 6 & 1.1 \\
\hline - Obsessive-compulsive disorder & 1 & 0.2 \\
\hline - Dissociative disorder & 5 & 0.9 \\
\hline - Substance abuse & 3 & 0.6 \\
\hline - Psychosis & 23 & 4.2 \\
\hline Cardiovascular diseases & 37 & 6.8 \\
\hline - Coronary artery disease & 16 & 2.9 \\
\hline - Hypertension & 37 & 6.7 \\
\hline - Congestive heart failure & 2 & 0.4 \\
\hline Respiratory system diseases & 6 & 1.1 \\
\hline Renal diseases & 3 & 0.6 \\
\hline Thyroid diseases & 10 & 1.8 \\
\hline Autoimmune diseases & 4 & 0.8 \\
\hline - Rheumatoid arthritis & 1 & 0.2 \\
\hline - Lupus erythematosus & 1 & 0.2 \\
\hline - Multiple sclerosis & 1 & 0.2 \\
\hline - Celiac disease & 1 & 0.2 \\
\hline Oncologic diseases not involving brain & 5 & 0.9 \\
\hline Others & 4 & 0.8 \\
\hline - Sarcoidosis & 1 & 0.2 \\
\hline - FMF & 1 & 0.2 \\
\hline - Parkinson's disease & 1 & 0.2 \\
\hline - Essential tremor & 1 & 0.2 \\
\hline
\end{tabular}




\section{Discussion}

Epilepsy is a disorder characterized by repetitive, nonprovoking seizures that occur due to excessive electrical activity in brain cells. Although epilepsy affects both sexes, it is more common in males, which has been shown in many studies. The male/female ratio ranges from 1.1 to $1.4: 1$, which is thought to be a non-significant difference. Male predominance can be caused by more frequent exposure to trauma due to being more active in social life and working in heavy and dangerous jobs $(6,13,15,16)$.

However, the difference in prevalence according to sex was not supported by some studies. In a study of epilepsy associated with localization, cryptogenic and idiopathic epilepsy were shown to be common in females, whereas secondary epilepsy associated with a local epileptogenic focus is widespread in males $(17,18)$. We found the male/female ratio as 1.1:1 in our study, which was not significantly different $(\mathrm{p}=0.44)(19)$, and was similar to a study's result from North Sweden. In addition, there was no difference between the sexes in terms of age of onset and duration of epilepsy.

According to some studies, the incidence of epilepsy, which is primarily known as a childhood disease, shows a bimodal U-peak pattern in children and elderly (20). On the other hand, studies performed in late adolescent and adult populations found the highest prevalence in adults and decreased prevalence after 50 years of age. Some studies showed an increased prevalence of epilepsy again after 70 years of age $(15,19)$. In our study, approximately half

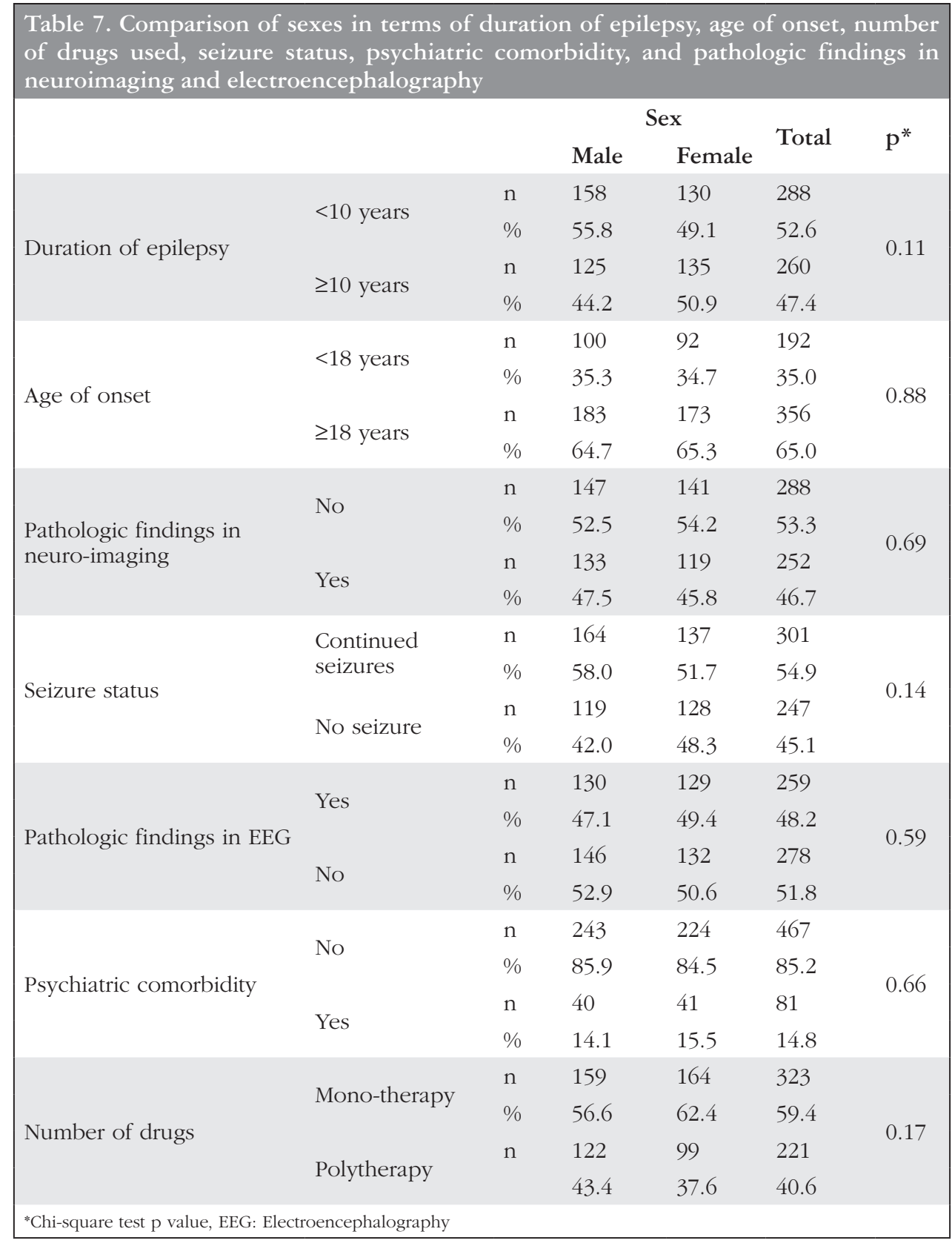


of the patients (46\%) had epilepsy between the ages of $18-50$ years and the frequency was decreased after the age of 50 years $(19 \%)$.

According to the seizure classification of the International League Against Epilepsy, seizures are divided into three main classes: generalized, focal, and undefined-onset seizures. Generalized-onset seizures include motor and non-motor, undefined- onset seizures include motor, non-motor, and unclassified seizures. Partial-onset seizures include motor and non-motor seizures with or without impairment of consciousness and focal-onset bilateral tonic-clonic seizures (21).

The determination of seizure type depends on the correct description of the patient or their relatives, the observation of the seizure by the physician, the results of diagnostic examinations such as EEG and CCT/MRI and the age of the patient (16). Many studies have shown that focal-onset seizures are more frequent. Such seizures are common, especially in adult and elderly patients. In younger children, generalized-onset seizures are observed more frequently. This rate shifts to partial-onset seizures with age $(4,15,16,20)$.

Approximately 20-30\% of patients with epilepsy had more than one seizure per month (2). Similarly, in another study, $17 \%$ of patients had seizures in the last week and $57 \%$ in the last year. In contrast, only $16 \%$ of patients had a 5 -year seizure-free period (19).

In accordance with the literature, most patients (42.0\%) had seizures several times a year. Thirteen percent of patients had more than one seizure per month. One-year seizure-freedom was $12.6 \%$, 3-year was $7.7 \%$, and 5 -year was $8.9 \%$. There was no difference between the sexes in terms of seizure frequency. Focalonset seizures were detected in $54.8 \%$ of patients. This ratio can be explained by the inclusion of only adult patients in our study. In particular, the frequent focal-onset seizures in adults was due to the etiology of epilepsy. The most common causes of symptomatic epilepsy presenting with focal-onset seizures were head trauma,

\begin{tabular}{|c|c|c|c|c|c|c|}
\hline & & & $\begin{array}{l}\text { Pat } \\
\text { in }\end{array}$ & $\begin{array}{l}\text { findings } \\
\text { maging }\end{array}$ & Total & $\mathrm{p}^{*}$ \\
\hline & & & Yes & No & & \\
\hline \multirow{4}{*}{ Seizure status } & \multirow{2}{*}{ Continuing } & $\mathrm{n}$ & 147 & 148 & 295 & \multirow{4}{*}{0.12} \\
\hline & & $\%$ & 58.3 & 51.6 & 54.7 & \\
\hline & \multirow{2}{*}{ None } & $\mathrm{n}$ & 105 & 139 & 244 & \\
\hline & & $\%$ & 41.7 & 48.4 & 45.3 & \\
\hline \multirow{4}{*}{ Duration of epilepsy } & \multirow{2}{*}{$<10$ years } & $\mathrm{n}$ & 136 & 149 & 285 & \multirow{4}{*}{0.63} \\
\hline & & $\%$ & 54.0 & 51.9 & 52.9 & \\
\hline & \multirow{2}{*}{$\geq 10$ years } & $\mathrm{n}$ & 116 & 138 & 254 & \\
\hline & & $\%$ & 46.0 & 48.1 & 47.1 & \\
\hline \multirow{4}{*}{ Number of drugs used } & \multirow{2}{*}{ Monotherapy } & $\mathrm{n}$ & 144 & 175 & 319 & \multirow{4}{*}{0.27} \\
\hline & & $\%$ & 57.1 & 61.8 & 59.6 & \\
\hline & \multirow{2}{*}{ Polytherapy } & $\mathrm{n}$ & 108 & 108 & 216 & \\
\hline & & $\%$ & 42.9 & 38.2 & 40.4 & \\
\hline \multirow{4}{*}{ Age of onset } & \multirow{2}{*}{$<18$ years } & $\mathrm{n}$ & 73 & 115 & 188 & \multirow{4}{*}{0.007} \\
\hline & & $\%$ & 29.0 & 40.1 & 34.9 & \\
\hline & \multirow{2}{*}{$\geq 18$ years } & $\mathrm{n}$ & 179 & 172 & 351 & \\
\hline & & $\%$ & 71.0 & 59.9 & 65.1 & \\
\hline \multirow{4}{*}{$\begin{array}{l}\text { Pathologic findings in } \\
\text { EEG }\end{array}$} & \multirow{2}{*}{ Yes } & $\mathrm{n}$ & 139 & 117 & 256 & \multirow{4}{*}{0.001} \\
\hline & & $\%$ & 56.3 & 41.5 & 48.4 & \\
\hline & \multirow{2}{*}{ No } & $\mathrm{n}$ & 108 & 165 & 273 & \\
\hline & & $\%$ & 43.7 & 58.5 & 51.6 & \\
\hline \multirow{4}{*}{ Psychiatric disease } & \multirow{2}{*}{ No } & $\mathrm{n}$ & 243 & 216 & 459 & \multirow{4}{*}{0.66} \\
\hline & & $\%$ & 84.4 & 85.7 & 85.0 & \\
\hline & \multirow{2}{*}{ Yes } & $\mathrm{n}$ & 45 & 36 & 81 & \\
\hline & & & 15.6 & 14.3 & 15.0 & \\
\hline
\end{tabular}


cerebrovascular diseases, intracerebral tumors, and CNS infections. However, pre- and perinatal diseases such as asphyxia, febrile convulsions, and family history of epilepsy were emphasized as important risk factors. Canpolat et al. (6) showed that $40 \%$ of patients had febrile convulsions and $33 \%$ had a family history of epilepsy. In addition, low socioeconomic status, low level of education, homelessness, difficulties in living in rural areas, and access to health institutions have also been cited as risk factors $(16,22)$.

The frequency of posttraumatic seizures varies between $4 \%$ and $53 \%$ depending on the age of the patients, the severity of the trauma, and the duration following the trauma (23). Chen et al. (24) showed that posttraumatic epilepsy (PTE) developed in $35.2 \%$ of patients following severe head trauma. The risk factors for the development of PTE included age at the time of head trauma, having surgical intervention, having simple partial seizures, and the onset of seizures within the first 6 months following the trauma.

Stroke among cerebrovascular diseases is an important risk factor for the development of epilepsy. Studies have shown that approximately $10 \%$ of patients develop seizures following an ischemic or hemorrhagic stroke. The risk factors for post-stroke epilepsy have been reported as having hemorrhagic stroke, cortical involvement, and stroke involving multiple lobes (25).
However, in a recent study, two major risk factors were defined for poststroke epilepsy: high National Institute of Health score and venous sinus thrombosis. It has been shown that cerebrovascular risk factors and localization of stroke did not affect the development of epilepsy after stroke. However, following venous sinus thrombosis, hemorrhagic stroke was the second most common type of stroke causing post-stroke epilepsy (26). Wang et al. (27) showed that the frequency of early epileptic seizures following ischemic stroke was low (3.3\%).

In our study, most of the patients $(52.2 \%)$ had risk factors for epilepsy. Epilepsy and/or febrile seizure history in childhood $(35.2 \%)$ was the most common, and cerebral insult due to perinatal pathology (18.3\%) was the second most common risk factor found in our study. These were followed by cerebrovascular pathology $(9.9 \%)$, intracranial operations $(8.2 \%)$, brain tumors $(5.7 \%)$, and dementia and head traumas $(2.4 \%)$. We believe that the low frequency of epilepsy in the family (3.3\%) may be due to the lack of public awareness of the disease and cultural factors such as keeping the disease as a secret inside the family.

CNS infections, congenital metabolic and degenerative diseases, hydrocephalus and encephalopathy are rare diseases that play a smaller role as a cause of epilepsy. Ramantani and Holthausen (28) showed that the risk of development of seizures after CNS infection was $7-8 \%$ in developed countries.

\begin{tabular}{|c|c|c|c|c|c|c|}
\hline & & & \multicolumn{2}{|c|}{ Psychiatric disease } & \multirow[t]{2}{*}{ Total } & \multirow[t]{2}{*}{$\mathrm{p}^{*}$} \\
\hline & & & No & Yes & & \\
\hline \multirow{4}{*}{$\begin{array}{l}\text { Pathologic findings in } \\
\text { EEG }\end{array}$} & \multirow{2}{*}{ Yes } & $\mathrm{n}$ & 42 & 37 & 79 & \multirow{4}{*}{0.26} \\
\hline & & $\%$ & 54.5 & 45.7 & 50.0 & \\
\hline & \multirow{2}{*}{ No } & $\mathrm{n}$ & 35 & 44 & 79 & \\
\hline & & $\%$ & 45.5 & 54.3 & 50.0 & \\
\hline \multirow{4}{*}{ Duration of epilepsy } & \multirow{2}{*}{$<10$ years } & $\mathrm{n}$ & 51 & 33 & 84 & \multirow{4}{*}{0.005} \\
\hline & & $\%$ & 63.0 & 40.7 & 51.9 & \\
\hline & \multirow{2}{*}{$\geq 10$ years } & $\mathrm{n}$ & 30 & 48 & 78 & \\
\hline & & $\%$ & 37.0 & 59.3 & 48.1 & \\
\hline \multirow{4}{*}{ Number of drugs used } & \multirow{2}{*}{ Monotherapy } & $\mathrm{n}$ & 58 & 35 & 93 & \multirow{4}{*}{0.000} \\
\hline & & $\%$ & 71.6 & 43.2 & 57.4 & \\
\hline & \multirow{2}{*}{ Polytherapy } & $\mathrm{n}$ & 23 & 46 & 69 & \\
\hline & & $\%$ & 28.4 & 56.8 & 42.6 & \\
\hline \multirow{4}{*}{ Seizure status } & \multirow{2}{*}{$\begin{array}{l}\text { Continuing } \\
\text { seizures }\end{array}$} & $\mathrm{n}$ & 44 & 54 & 98 & \multirow{4}{*}{0.11} \\
\hline & & $\%$ & 54.3 & 66.7 & 60.5 & \\
\hline & \multirow{2}{*}{ No seizure } & $\mathrm{n}$ & 37 & 27 & 64 & \\
\hline & & $\%$ & 45.7 & 33.3 & 39.5 & \\
\hline \multirow{4}{*}{ Age of onset } & \multirow{2}{*}{$<18$ years } & $\mathrm{n}$ & 31 & 23 & 54 & \multirow{4}{*}{0.18} \\
\hline & & $\%$ & 57.4 & 42.6 & 100.0 & \\
\hline & \multirow{2}{*}{$\geq 18$ years } & $\mathrm{n}$ & 50 & 58 & 108 & \\
\hline & & & 46.3 & 53.7 & 100.0 & \\
\hline
\end{tabular}


In this case, the finding of lesions in cranial MRI and the development of SE during acute infection were shown to be the most important risk factors for the development of seizures after CNS infection. In this study, the most common rare risk factor was CNS infection (1.5\%), which was followed by congenital metabolic diseases $(1.2 \%)$, and encephalopathy and hydrocephaly $(0.8 \%)$.

Neuroimaging (CCT and MRI) in patients with epilepsy is used to determine the structural pathology of the brain, to diagnose the etiology of the disease, and to determine the approach to the disease (29). Magnetic resonance spectroscopy and positron emission tomography can show functional anatomy and neurochemical circuits that play a role in pathogenesis because no pathology has been detected in standard neuroimaging in idiopathic generalized epilepsies (30).

According to the literature, the rate of pathologic findings in neuroimaging of patients with epilepsy ranges from $17 \%$ to $70 \%$. It is thought that such a wide range depends on the population and seizure types involved in the studies. For example, in a study involving only children, generalized seizures were found in $77 \%$ of patients, and pathologic findings were found in only $17 \%$ of MR images. These were periventricular leukomalacia (4\%), left hippocampal sclerosis (2\%), cerebellar dysgenesis and thinning of brainstem (2\%), encephalomalacia ( $1 \%)$, bilateral occipital gliosis $(1 \%)$, bilateral hippocampal sclerosis $(1 \%)$, cerebral atrophy (1\%), porencephalic cyst (1\%), left occipital gliosis (1\%), and left parahippocampal arachnoid cyst (1\%) (6).

On the other hand, in a study in which $62 \%$ of the adult patients had partial seizures, MRI showed pathologic findings in $71 \%$ of all patients. These findings were isolated hippocampal sclerosis (21\%), cerebral cortical dysgenesis (8\%), isolated hippocampal sclerosis with dual pathology of any kind (4\%), tumors $(5 \%)$, vascular malformations $(6 \%)$, various scars $(14 \%)$, and various other brain abnormalities (13\%) (31).

Although the rate of detection of pathologies that may cause epilepsy is similar to CCT and MRI, abnormalities such as hippocampal mesial sclerosis can only be detected with MRI. Therefore, cranial MRI should be performed in patients with epilepsy who have normal brain tomography except for patients with primary generalized epilepsy $(14,32)$. Further, the findings of single-photon emission computed tomography rather than the findings of interictal MRI may be consistent with EEG findings and may be a better test to determine the focus of epilepsy (33).

In $46.8 \%$ of the patients in our study, pathologic findings were found in neuroimaging, and most $(78.2 \%)$ were single lesions. Similar results were reported by Mengistu et al. (29). In 35.9\% of the patients in that study, pathologic findings were detected in neuroimaging. Single lesions were found in $42.8 \%$ of patients and multiple lesions in $35.4 \%$. In the same study, pathologic findings were detected in $40.3 \%$ of patients. Of these lesions, $10.5 \%$ were encephalomalacia, $8.9 \%$ were ischemic gliotic lesions, $5.6 \%$ were congenital malformations, $4 \%$ were mesial temporal sclerosis, $4 \%$ were arachnoid cysts, $2.4 \%$ were cranial tumors, $2.4 \%$ were cerebral atrophy, $1.6 \%$ were subdural hygroma and $0.8 \%$ were metal images (14).

In our study, there was no difference between the sexes in terms of the presence of pathologic findings in neuroimaging.
However, the presence of lesions in neuro imaging was significant with the onset of epilepsy at age 18 years and over $(p=0.007)$. These findings are consistent with the fact that symptomatic epilepsy and partial seizures are more frequent in adults.

Since the second half of the $20^{\text {th }}$ century, EEG has been involved in neurophysiologic studies and has taken an indispensable role in neurologic practice to show the electrical activity of the brain. EEG helps to diagnose epilepsy, identify epileptic syndromes, and identify the localization of epileptic focus. However, the detection of epileptiform activity in EEG does not always diagnose epilepsy because epileptiform discharges in EEG may occur in healthy individuals, albeit rarely $(0.5 \%)$. In the same way, the normal EEG does not exclude the diagnosis of epilepsy. In the initial routine interictal EEG, the probability of detecting epileptiform activity is approximately $50 \%$, and in repeated recordings, this rate may increase to 80$90 \%$. It is therefore important to note that it is always necessary to evaluate EEG results in light of clinical findings (34).

In the literature, $33.1 \%$ to $65 \%$ of patients with epilepsy had abnormalities in EEG $(14,29,32)$. In our study, pathologic findings were found in 259 patients (48.2\%) in interictal EEG during the last admission, similar to the results in the literature. There was no difference between the sexes in terms of pathologic findings in EEG. However, patients with lesions had significantly more pathologic EEGs compared with patients without lesions $(\mathrm{p}=0.001)$. These findings suggest that the underlying cerebral pathology may trigger discharges detected in EEG.

The aim of epilepsy treatment is to provide seizure freedom and improve the quality of life of patients. The main principle of medical treatment is to start treatment with monotherapy suitable for seizure type. Seizure control with the first started antiepileptic drug can be achieved in about $40-50 \%$ of patients (35). This rate was found as $15.9 \%$ in our study.

The success of treatment depends largely on the compatibility that patients show with their treatment. One study showed that only $59.1 \%$ of patients used their medication regularly. The causes of irregular use of treatment were neglect $(72.3 \%)$, forgetfulness $(85.1 \%)$, boredom $(55.3 \%)$, and the adverse effects of drugs (48.9\%). In the same study, it was found that the quality of life of patients using regular treatment was higher (13).

If seizures continue despite the first initiated drug, it is necessary to increase the dose of the drug, change the drug, or switch to polytherapy. Ünal et al. (14) reported that $49.0 \%$ of patients received monotherapy, and $34.6 \%$ received polytherapy in their study. In addition, $28.5 \%$ of patients had drug-resistant epilepsy. In our study, $59.4 \%$ of the patients received monotherapy, and $40.6 \%$ received polytherapy, and $13 \%$ of the patients were using three or more antiepileptic drugs due to drug-resistant epilepsy. There was no difference in the number of antiepileptic drugs used between sexes. Patients whose seizures cannot be controlled with medical treatment can be evaluated in terms of epilepsy surgery. In our follow-up, there were no patients undergoing epilepsy surgery. A patient with resistant temporal lobe epilepsy using 5 antiepileptic drugs was offered surgery, but the patient did not accept. 
Comorbidity is defined as the presence of multiple diseases in the same person without any causal relationship. However, a cause and effect relationship between these two diseases sometimes arises (35). At least one comorbid disease is present in approximately $50 \%$ of patients with active epilepsy. It was shown in studies that comorbid diseases were detected 8 times more in patients with epilepsy than in the general population. Comorbid diseases affect the prognosis of epilepsy, the success of treatment, and compliance with treatment and quality of life (36).

Comorbidities may be related with the etiology of epilepsy, epilepsy itself, and the adverse effects of antiepileptic drugs. Common mechanisms may play a role in the development of epilepsy and comorbid conditions. For example, perinatal hypoxemia can cause both epilepsy and spastic hemiparesis associated with epilepsy. On the other hand, many diseases such as brain tumors, stroke, and Alzheimer's disease can form both risk factor or comorbid condition for epilepsy (36). It has been shown that comorbidities including migraine, neuropathic pain, fibromyalgia, allergy, type 1 diabetes, asthma, arthritis, and cardiac diseases are common among patients with epilepsy, leading to fatigue, energy loss, and a decrease in quality of life in patients with multiple comorbidities $(36,37,38)$. In addition, cardiac arrhythmia and gastrointestinal symptoms are seen more frequently in patients taking antiepileptic drugs (39).

Psychiatric disorders are seen at least 2-3 times more frequently in patients with epilepsy than in the healthy population. In one study, the prevalence of depression in patients with epilepsy was $23.1 \%$, anxiety was $22.8 \%$, interictal psychosis was $5.2 \%$, personality disorders were $4-38 \%$, and suicide was $5-14.3 \%$ (40). Another study revealed a comorbid relationship between epilepsy and anxiety, depression, bipolar disorder, carelessness, and hyperactivity syndrome (37).

In our study, the rate of comorbidity was $27.7 \%$. When evaluating comorbidity, diseases with no etiologic connection with epilepsy were considered. If we counted the conditions etiologically related with epilepsy such as stroke, tumor, and dementia, then the comorbidity rate would be much higher. According to the results of our study, the most frequent diseases associated with epilepsy were depression, anxiety, bipolar disorder, psychosis, obsessive-compulsive disorder, dissociative disorder, and psychiatric disorders including substance abuse (15.2\%). The most common ones were depression (4.4\%), anxiety $(3.8 \%)$, and psychotic disorder (4.2\%). In addition, the duration of epilepsy in patients with psychiatric symptoms was longer $(p=0.005)$, and the number of antiepileptic drugs used was higher $(\mathrm{p}<0.001)$. There was no difference between patients with and without a psychiatric illness in terms of having abnormal EEG, seizure status, and age of onset. There was no difference between sexes in terms of psychiatric comorbidity.

\section{Conclusion}

The results of our study reflect the status of epilepsy in our province and show parallelism with the literature. We think that our study will contribute to the enlightenment of the demographic status of epilepsy in Turkey.

Acknowledgements: Thanks Dr. Recep Minga for his help in biostatistical analyses.

\section{Ethics}

Ethics Committee Approval: The study were approved by the Ethical Board of Clinical Research of Erzincan University (date: 26.09.2017, protokol number: 13/04).

Informed Consent: Consent form was filled out by all participants.

Peer-review: Externally peer-reviewed.

\section{Authorship Contributions}

Concept: A.E., Design: A.E., C.T., Data Collection or Processing: A.E., C.T., H.Y., T.Ö.G., Analysis or Interpretation: A.E., Literature Search: A.E., Writing: A.E., C.T.

Conflict of Interest: No conflict of interest was declared by the authors.

Financial Disclosure: No financial support was received from any institution or person for our study.

\section{References}

1. Fisher RS, van Emde Boas W, Blume W, et al. Epileptic seizures and epilepsy: definitions proposed by the International League Against Epilepsy (ILAE) and the International Bureau for Epilepsy (IBE). Epilepsia 2005;46:470472.

2. Forsgren L, Beghi E, Oun A, Sillanpaa M. The epidemiology of epilepsy in Europe - a systematic review. Eur J Neurol 2005;12:245-253.

3. Gracia F, de Lao SL, Castillo L, et al. Epidemiology of epilepsy in Guaymi Indians from Bocas del Toro Province, Republic of Panama. Epilepsia 1990;31:718-723.

4. Yeni SN. Epidemiology of Epilepsy Turkiye Klinikleri J Neurol-Special Topics 2008;1:9-16.

5. Senanayake N, Roman GC. Epidemiology of epilepsy in developing countries. Bull World Health Organ 1993;71:247-258.

6. Canpolat M, Kumandas S, Poyrazoglu HG, Gumus H, Elmali F, Per H. Prevalence and risk factors of epilepsy among school children in Kayseri City Center, an urban area in Central Anatolia, Turkey. Seizure 2014;23:708-716.

7. Unver O, Keskin SP, Uysal S, Unver A. The epidemiology of epilepsy in children: a report from a Turkish pediatric neurology clinic. J Child Neurol 2015;30:698-702.

8. Tekeli H, Yaşar H, Kendli MT, Şenol MG, Özdağ F, Saraçoğlu M. The Prevalence of Epilepsy in Young Turkish Males. Epilepsi 2012;18:1-6.

9. Kılınçer A EÇ, Ergin A, Acar G, Şahiner T. Denizli İl Merkezinde Epilepsi Prevalansi. Pamukkale Tip Dergisi 2012;5:110-114.

10. Reynolds EH. The ILAE/IBE/WHO Global Campaign against Epilepsy: Bringing Epilepsy "Out of the Shadows". Epilepsy Behav 2000;1:S3-S8.

11. Meyer AC, Dua T, Ma J, Saxena S, Birbeck G. Global disparities in the epilepsy treatment gap: a systematic review. Bull World Health Organ 2010;88:260-266.

12. ILAE Commission Report. The epidemiology of the epilepsies: future directions. International League Against Epilepsy. Epilepsia 1997;38:614618.

13. Acaroğlu G YE. Epilepsili Hastalarda İlaç Uyumunun Yaşam Kalitesine Etkisi Epilepsi 2016;22:17-25.

14. Ünal Y, Aslan Öztürk D, Yılmaz M, Kutlu G. Muğla Sıtkı Koçman Üniversitesi Tip Fakültesi'nde Yeni Kurulan Epilepsi Polikliniği'nde Takip Edilen Hastaların Demografik ve Klinik Bulguları. Epilepsi 2016;22:5-11.

15. Picot MC, Baldy-Moulinier M, Daures JP, Dujols P, Crespel A. The prevalence of epilepsy and pharmacoresistant epilepsy in adults: a population-based study in a Western European country. Epilepsia 2008;49:1230-1238.

16. Banerjee PN, Filippi D, Allen Hauser W. The descriptive epidemiology of epilepsy-a review. Epilepsy Res 2009;85:31-45.

17. Fiest KM, Sauro KM, Wiebe S, et al. Prevalence and incidence of epilepsy: A systematic review and meta-analysis of international studies. Neurology 2017;88:296-303.

18. Christensen J, Kjeldsen MJ, Andersen H, Friis ML, Sidenius P. Gender differences in epilepsy. Epilepsia 2005;46:956-960. 
19. Forsgren L. Prevalence of epilepsy in adults in northern Sweden. Epilepsia 1992;33:450-458.

20. Kotsopoulos IA, van Merode T, Kessels FG, de Krom MC, Knottnerus JA. Systematic review and meta-analysis of incidence studies of epilepsy and unprovoked seizures. Epilepsia 2002;43:1402-1409.

21. Fisher RS, Cross JH, D'Souza C, et al. Instruction manual for the ILAE 2017 operational classification of seizure types. Epilepsia 2017;58:531-542.

22. Ogunrin OA, Obiabo OY, Obehigie E. Risk factors for epilepsy in Nigerians - a cross-sectional case-control study. Acta Neurol Scand 2014;129:109-113.

23. Frey LC. Epidemiology of posttraumatic epilepsy: a critical review. Epilepsia 2003;44(Suppl 10):11-17.

24. Chen W, Li MD, Wang GF, Yang XF, Liu L, Meng FG. Risk of post-traumatic epilepsy after severe head injury in patients with at least one seizure. Neuropsychiatr Dis Treat 2017;13:2301-2306.

25. Lancman ME, Golimstok A, Norscini J, Granillo R. Risk factors for developing seizures after a stroke. Epilepsia 1993;34:141-143.

26. Conrad J, Pawlowski M, Dogan M, Kovac S, Ritter MA, Evers S. Seizures after cerebrovascular events: risk factors and clinical features. Seizure 2013;22:275-282.

27. Wang JZ, Vyas MV, Saposnik G, Burneo JG. Incidence and management of seizures after ischemic stroke: Systematic review and meta-analysis. Neurology 2017;89:1220-1228.

28. Ramantani G, Holthausen H. Epilepsy after cerebral infection: review of the literature and the potential for surgery. Epileptic Disord 2017;19:117-136.

29. Mengistu G, Ewunetu BD, Johnston JC, Metaferia GZ. Neuroimaging of Ethiopian patients with epilepsy: a retrospective review. Ethiop Med J 2014;52:57-66.
30. Panayiotopoulos CP. Idiopathic generalized epilepsies: a review and modern approach. Epilepsia 2005;46(Suppl 9):1-6.

31. Semah F, Picot MC, Adam C, et al. Is the underlying cause of epilepsy a major prognostic factor for recurrence? Neurology 1998;51:1256-1262.

32. Yang PJ, Berger PE, Cohen ME, Duffner PK. Computed tomography and childhood seizure disorders. Neurology 1979;29:1084-1088.

33. Özışık Karaman HI, Canbaz Kabay S, Kamışlı Ö. Fokal EEG Anormalliği Olan Epilepsi Hastalarında Manyetik Rezonans Görüntüleme ve İnteriktal 99mtc-Hmpao Spect Bulguları Arasındaki İlişki. İnönü Üniversitesi Tıp Fakültesi 2011;18:91-95.

34. Vanli Yavuz EN, Bebek N. Epilepsi Tanı ve Tedavisinde Ektroensefalografinin (EEG) Yeri. Klinik Gelişim. 35-7 www.klinikgelisim.org.tr $/ \mathrm{kg} 10 \_1 / 5 . p d f$

35. Epilepsi Çalışma Grubu Tanı ve Tedavi Rehberi 2015 TÜRK NÖROLOJİ DERNEĞİ 2015 Epilepsi Çalışma Grubu Moderatörleri: Prof. Dr. S. Naz Yeni Prof. Dr. Candan Gürses. http://www.noroloji.org.tr/TNDData/ Uploads/files/Epilepsi\%202015\%20G\%C3\%BCncellenmi\%C5\%9F.pdf

36. Keezer MR, Sisodiya SM, Sander JW. Comorbidities of epilepsy: current concepts and future perspectives. Lancet Neurol 2016;15:106-115.

37. Ottman R, Lipton RB, Ettinger AB, et al. Comorbidities of epilepsy: results from the Epilepsy Comorbidities and Health (EPIC) survey. Epilepsia 2011;52:308-315.

38. Adebayo PB, Akinyemi RO, Oluwole F, Ogun SA, Ogunniyi A. Impact of somatic comorbidities on quality of life of patients living with epilepsy in Sagamu, Nigeria. Acta Neurol Scand 2014;130:387-393.

39. Tellez-Zenteno JF, Matijevic S, Wiebe S. Somatic comorbidity of epilepsy in the general population in Canada. Epilepsia 2005;46:1955-1962.

40. Josephson CB, Jette N. Psychiatric comorbidities in epilepsy. Int Rev Psychiatry 2017;29:409-424. 